\title{
Anti-influenza virus activity of extracts from the stems of Jatropha multifida Linn. collected in Myanmar
}

\author{
Masaki Shoji ${ }^{1 *}$, So-Yeun Woo ${ }^{2}$, Aki Masuda ${ }^{1}$, Nwet Nwet Win ${ }^{2,3}$, Hla Ngwe $^{3}$, Etsuhisa Takahashi ${ }^{4}$, Hiroshi Kido ${ }^{4}$, \\ Hiroyuki Morita², Takuya Ito ${ }^{2^{*}}$ and Takashi Kuzuhara ${ }^{1 *}$
}

\begin{abstract}
Background: To contribute to the development of novel anti-influenza drugs, we investigated the anti-influenza activity of crude extracts from 118 medicinal plants collected in Myanmar. We discovered that extract from the stems of Jatropha multifida Linn. showed anti-influenza activity. J. multifida has been used in traditional medicine for the treatment of various diseases, and the stem has been reported to possess antimicrobial, antimalarial, and antitumor activities. However, the anti-influenza activity of this extract has not yet been investigated.

Methods: We prepared water $\left(\mathrm{H}_{2} \mathrm{O}\right)$, ethyl acetate (EtOAc), $n$-hexane $(\mathrm{Hex})$, and chloroform $\left(\mathrm{CHCl}_{3}\right)$ extracts from the stems of $\mathrm{J}$. multifida collected in Myanmar, and examined the survival of Madin-Darby canine kidney (MDCK) cells infected with the influenza A (H1N1) virus, and the inhibitory effects of these crude extracts on influenza A viral infection and growth in MDCK cells.

Results: The $\mathrm{H}_{2} \mathrm{O}$ extracts from the stems of J. multifida promoted the survival of MDCK cells infected with the influenza A H1N1 virus. The EtOAc and $\mathrm{CHCl}_{3}$ extracts resulted in similar, but weaker, effects. The $\mathrm{H}_{2} \mathrm{O}$, EtOAc, and $\mathrm{CHCl}_{3}$ extracts from the stems of J. multifida inhibited influenza A virus $\mathrm{H} 1 \mathrm{~N} 1$ infection; the $\mathrm{H}_{2} \mathrm{O}$ extract possessed the strongest inhibitory effect on influenza infection in MDCK cells. The EtOAc, Hex, and $\mathrm{CHCl}_{3}$ extracts all inhibited the growth of influenza A H1N1 virus, and the $\mathrm{CHCl}_{3}$ extract demonstrated the strongest activity in MDCK cells.

Conclusion: The $\mathrm{H}_{2} \mathrm{O}$ or $\mathrm{CHCl}_{3}$ extracts from the stems of J. multifida collected in Myanmar demonstrated the strongest inhibition of influenza A H1N1 viral infection or growth in MDCK cells, respectively. These results indicated that the stems of J. multifida could be regarded as an anti-influenza herbal medicine as well as a potential crude drug source for the development of anti-influenza compounds.
\end{abstract}

Keywords: Anti-influenza, Anti-virus, Jatropha multifida, Stem, Herbal medicine

\section{Background}

In 1918, the Spanish influenza A (H1N1) virus pandemic caused 50 million deaths worldwide $[1,2]$. In 2009, influenza A virus originating in swine (H1N1) caused a pandemic, and the avian $\mathrm{H} 5 \mathrm{~N} 1$ and $\mathrm{H} 7 \mathrm{~N} 9$ influenza A viruses in China are highly pathogenic to humans [1-4]. Currently, the application of three antiviral medicines known

\footnotetext{
* Correspondence: masaki-shoji@ph.bunri-u.ac.jp; itot@inm.u-toyama.ac.jp; kuzuhara@ph.bunri-u.ac.jp

${ }^{1}$ Laboratory of Biochemistry, Faculty of Pharmaceutical Sciences, Tokushima Bunri University, 180 Yamashiro-cho, Tokushima 770-8514, Japan

${ }^{2}$ Institute of Natural Medicine, University of Toyama, 2630, Sugitani, Toyama 930-0194, Japan

Full list of author information is available at the end of the article
}

as neuraminidase (NA) inhibitors, oral oseltamivir, zanamivir, and peramivir, is recommended for the treatment of influenza. However, oseltamivir resistance has been detected in some of the 2009-derived H1N1 viruses and the seasonal H1N1 viruses between 2007 and 2009, but little in H3N2 viruses [5]. In the future, zanamivir- and peramivir-resistant strains, similar to oseltamivir-resistant strain, will emerge. Therefore, the development of novel anti-influenza drugs to prevent and control future influenza epidemics and pandemics is desired.

Traditional medicinal plants have been recognized as a rich source of candidate compounds for the development of pharmaceuticals $[6,7]$. A large number of natural 
products and extracts from medicinal plants have been reported to possess anti-influenza virus activity [8-10]. Therefore, many studies have focused on traditional medicinal plants as an important source of candidate compounds for the discovery of novel anti-influenza drugs.

The abundance of medicinal plants in Myanmar has enabled the population to use traditional medicines to maintain their own health and treat various diseases. Thus, to discover sources for novel anti-influenza drugs, we screened extracts from 118 medicinal plants collected in Myanmar to analyze the cell viability of influenza A H1N1 virus (A/PR/8/34)-infected MDCK cells using naphthol blue black staining. We identified six medicinal plants that promoted the survival of influenza A virus-infected cells selected by the criteria described at the Methods section. Of these six plants, the activity of extract from the stems of Jatropha multifida Linn (J. multifida) was strongly pronounced. J. multifida, a member of the family Euphorbiaceae, is a tree of $2-3 \mathrm{~m}$ in height, and widely distributed in sub-tropical and tropical areas throughout Asia and Africa [11]. Popularly known as "Say-ma-khan", it is commonly used as a folk medicine in Myanmar and has been used as a purgative, and against fever, indigestion, colic, wounds, and skin infection [11]. The seed oil, latex, and leaves are effective purgatives and abortifacients, have been used as wound dressings, and for the treatment of neurodermatitis, eczema, and itches [11]. The roots and stems have antimicrobial, antimalarial, antitumor, antileishmanial, and antiulcer activities [11, 12]. In addition, previous phytochemical studies on J. multifida reported the presence of cyclic peptides, diterpenoids, and phenolic compounds [11]. However, pharmacological and phytochemical investigations of $J$. multifida stems originating from Myanmar have not yet been conducted, which attracted us to investigate whether extracts from the stems of $J$. multifida, obtained using various solvents, possessed anti-influenza virus activity.

\section{Methods}

\section{Plant material}

The stems of $J$. multifida were purchased from Sandhi Brothers Trading Co. Ltd (Yangon, Myanmar) in November 2015. A voucher specimen (TMPW 28729) was deposited at the Museum of Materia Medica, Analytical Research Center for Ethnomedicines, Institute of Natural Medicine, University of Toyama, Japan.

\section{Plant extraction}

We performed the plant extraction as described previously $[13,14]$. In brief, dried stems of $J$. multifida were chopped into small pieces $(3.0 \mathrm{~kg})$, which were macerated four times with $70 \%$ aqueous $\mathrm{EtOH}(7 \mathrm{~L})$ in an ultrasonic bath for $90 \mathrm{~min}$ at $25{ }^{\circ} \mathrm{C}$. After filtration of the suspension, the resulting solution was evaporated under reduced pressure to yield a crude extract (180 g). The crude extract was suspended in water and partitioned into $n$-hexane (Hex), chloroform $\left(\mathrm{CHCl}_{3}\right)$, and ethyl acetate (EtOAc) fractions, to yield Hex-soluble (12.2 g), $\mathrm{CHCl}_{3}$-soluble (11.0 g), and EtOAc-soluble portions (11.0 g), respectively. Finally, the residual aqueous layer was evaporated under reduced pressure to yield a water $\left(\mathrm{H}_{2} \mathrm{O}\right)$-soluble portion $(140.8 \mathrm{~g})$. The extracts were stored at a concentration of $10 \mathrm{mg} / \mathrm{mL}$ in dimethyl sulfoxide (DMSO).

\section{Cells}

Madin-Darby canine kidney (MDCK) cells were cultured in high-glucose Dulbecco's modified Eagle's medium (DMEM; Wako, Osaka, Japan), supplemented with 10\% fetal bovine serum (FBS; Life Technologies, CA, USA), 50 units/mL penicillin and $50 \mu \mathrm{g} / \mathrm{mL}$ streptomycin (P/S; Life Technologies), and $4 \mathrm{mML}$-glutamine, at $37{ }^{\circ} \mathrm{C}$ in the presence of $5 \% \mathrm{CO}_{2}[15]$.

\section{Viral strain}

This study used the Puerto Rico 8/34 (A/PR/8/34; $\mathrm{H} 1 \mathrm{~N} 1)$ strain of the influenza A virus. Viral titers were determined by immunostaining influenza A viral nucleoprotein (NP) as previously described [16].

\section{Analysis of cell viability of influenza A virus-infected MDCK cells using naphthol blue black staining}

MDCK cells were seeded in a 96-well plate $\left(1 \times 10^{4}\right.$ cells/well). $\mathrm{H}_{2} \mathrm{O}$, EtOAc, $\mathrm{Hex}$, or $\mathrm{CHCl}_{3}$ extracts from the stems of $J$. multifida $(0.8-25 \mu \mathrm{g} / \mathrm{mL}$ in DMSO) were mixed with influenza A virus in 10\% FBS-supplemented growth medium at a multiplicity of infection (MOI) of 10 , and then incubated for $30 \mathrm{~min}$ at $37{ }^{\circ} \mathrm{C}$ in the presence of $5 \% \mathrm{CO}_{2}$. DMSO (0.008-0.5\%) and (+)-(S)-bakuchiol (0.8-25 $\mu \mathrm{M}$ in DMSO) were used as negative and positive controls, respectively, for the inhibition of influenza A viral infection [15]. The mixture was added to the cells, which were then incubated for 4 days at $37{ }^{\circ} \mathrm{C}$ in the presence of $5 \% \mathrm{CO}_{2}$. After incubation, the cells were stained using naphthol blue black as previously described $[15,17]$. The viable cells in each well were stained blue, while dead cells remained unstained. The selection criteria for the six plants are more than 50\% cell survival at $96 \mathrm{~h}$ after the viral infection with the concentration of $50 \mu \mathrm{g} / \mathrm{mL}$.

\section{Thiazolyl blue tetrazolium bromide (MTT) assay}

MDCK cells were seeded in each well of a 96-well plate $\left(1 \times 10^{4}\right.$ cells/well). $\mathrm{H}_{2} \mathrm{O}$, EtOAc, $\mathrm{Hex}$, or $\mathrm{CHCl}_{3}$ extracts $(12.5-100 \mu \mathrm{g} / \mathrm{mL})$ were prepared in DMSO $(12.5 \mu \mathrm{g} / \mathrm{mL}$, 0.125\%; $25 \mu \mathrm{g} / \mathrm{mL}, 0.25 \% ; 50 \mu \mathrm{g} / \mathrm{mL}, 0.5 \% ; 100 \mu \mathrm{g} / \mathrm{mL}$, $1 \%$ ) and mixed with infection medium (DMEM supplemented with $1 \%$ bovine serum albumin [BSA; Wako, 
Osaka, Japan], P/S, and $4 \mathrm{mM}$ L-glutamine). The mixture was added to the cells, which were then incubated for 24,72 , or $96 \mathrm{~h}$ at $37^{\circ} \mathrm{C}$ in the presence of $5 \% \mathrm{CO}_{2}$. After incubation, cell viability was determined using the MTT cell proliferation assay as previously described [15].

\section{Immunofluorescence staining of influenza A virus- infected cells}

MDCK cells were seeded in a 96-well plate $\left(1 \times 10^{4}\right.$ cells/ well). $\mathrm{H}_{2} \mathrm{O}$, EtOAc, $\mathrm{Hex}$, or $\mathrm{CHCl}_{3}$ extracts from the stems of $J$. multifida $(3.1-25 \mu \mathrm{g} / \mathrm{mL})$ or $(+)-(S)$-bakuchiol (3.1-25 $\mu \mathrm{M})$ were mixed with influenza $\mathrm{A}$ virus at a MOI of 0.1 in the infection medium and incubated for $30 \mathrm{~min}$ at $37{ }^{\circ} \mathrm{C}$ in the presence of $5 \% \mathrm{CO}_{2}$. DMSO $(0.031-0.25 \%)$ was used as the negative control. Each mixture was added to the cells and incubated for $24 \mathrm{~h}$ at $37{ }^{\circ} \mathrm{C}$ in the presence of $5 \% \mathrm{CO}_{2}$. The cells were fixed with $4 \%$ paraformaldehyde in PBS for $30 \mathrm{~min}$ at $4{ }^{\circ} \mathrm{C}$ and then permeabilized by the addition of $0.3 \%$ Triton $\mathrm{X}-100$ for $20 \mathrm{~min}$ at $25^{\circ} \mathrm{C}$. A mouse antibody for the detection of the NP of A/PR/8/34 (FluA-NP 4 F1; SouthernBiotech, AL, USA) was used as the primary antibody. Alexa Fluor488-conjugated goat anti-mouse IgG $(\mathrm{H}+\mathrm{L})$ antibody (Life Technologies, CA, USA) was used as the secondary antibody. Cell nuclei were then stained using diamidino-2-phenylindole (DAPI; Life Technologies). The wells were photographed using a fluorescence microscope (BIOREVO BZ-9000, Keyence, Osaka, Japan), and the percentage of influenza A NPpositive cells per DAPI-positive cells were calculated based on measurements recorded with BZ-H1C software (Keyence).

\section{Influenza A viral growth assay}

To explore whether the extracts from the stems of $J$. multifida affected viral growth in pre-infected cells, MDCK cells were seeded in a 24-well plate $\left(1 \times 10^{5}\right.$ cells/well). The cells were infected with $\mathrm{A} / \mathrm{PR} / 8 / 34$ (MOI; 0.001) in infection medium for $1 \mathrm{~h}$ at $37^{\circ} \mathrm{C}$ in the presence of $5 \% \mathrm{CO}_{2}$. The infected cells were washed prior to the addition of $\mathrm{H}_{2} \mathrm{O}, \mathrm{EtOAc}, \mathrm{Hex}$, or $\mathrm{CHCl}_{3} \mathrm{~J}$. multifida extracts ( 12.5 or $25 \mu \mathrm{g} / \mathrm{mL}$ in $0.5 \%$ DMSO) to the cells in infection medium supplemented with $3 \mu \mathrm{g} /$ mL L-tosylamido-2-phenyl ethyl chloromethyl ketone (TPCK)-treated trypsin (Sigma-Aldrich). DMSO (0.5\%) and ribavirin $(50 \mu \mathrm{M}$ in $0.5 \%$ DMSO) were the negative and positive controls, respectively, for the inhibition on influenza A viral growth [18]. The cells were then incubated for 24,48 , or $72 \mathrm{~h}$ at $37{ }^{\circ} \mathrm{C}$ in the presence of $5 \%$ $\mathrm{CO}_{2}$. Cell culture media were collected from each well at predetermined time points. Viral titers (plaque forming units per $\mathrm{mL}[\mathrm{PFU} / \mathrm{mL}]$ ) were determined as previously described [15].

\section{Statistical analysis}

All results were expressed as the mean \pm the standard error of the mean (SEM). Differences between more than two groups were analyzed for statistical significance by using one-way analysis of variance (ANOVA). Values of $p<0.05$ were considered statistically significant.

\section{Results}

Extracts from the stems of $J$. multifida increased the survival of influenza A viral-infected MDCK cells

To evaluate the anti-influenza viral activity of extracts from the stems of $J$. multifida, we first examined the survival of influenza A virus-infected MDCK cells after treatment with the $\mathrm{H}_{2} \mathrm{O}$, EtOAc, $\mathrm{Hex}$, or $\mathrm{CHCl}_{3}$ extracts from the stems of $J$. multifida. As shown in Fig. 1, cells exposed to DMSO and infected with $\mathrm{A} / \mathrm{PR} / 8 / 34$ were not stained. However, cells treated with 3.1-25 $\mu \mathrm{M}$ (+)-(S)-bakuchiol or 3.1-25 $\mu \mathrm{g} / \mathrm{mL} \mathrm{H}_{2} \mathrm{O}$ extract and infected with $\mathrm{A} / \mathrm{PR} / 8 / 34$ were stained blue. Cells exposed to $25 \mu \mathrm{g} / \mathrm{mL}$ EtOAc or $12.5-25 \mu \mathrm{g} / \mathrm{mL} \mathrm{CHCl}_{3}$ extract and infected with $\mathrm{A} / \mathrm{PR} / 8 / 34$ were also weakly stained blue (Fig. 1).

To evaluate cytotoxicity, we determined the viability of MDCK cells after incubation for 24, 72, or $96 \mathrm{~h}$ in infection medium containing BSA using the MTT assay (Fig. 2). The viability of MDCK cells treated with $\mathrm{H}_{2} \mathrm{O}$, EtOAc, $\mathrm{Hex}$, or $\mathrm{CHCl}_{3}$ extract from the stems of $J$. multifida was unaffected after $24 \mathrm{~h}$, compared with cells exposed to DMSO only (Fig. 2a). After 72 or $96 \mathrm{~h}$ of incubation, the viability of MDCK cells treated with $100 \mu \mathrm{g} / \mathrm{mL} \mathrm{H}_{2} \mathrm{O}$ or $12.5-100 \mu \mathrm{g} / \mathrm{mL} \mathrm{CHCl}_{3}$ extracts significantly reduced (Fig. 2b), whereas the viability of cells exposed to $\leq 50 \mu \mathrm{g} / \mathrm{mL} \mathrm{H}_{2} \mathrm{O}, \leq 100 \mu \mathrm{g} / \mathrm{mL}$ EtOAc and

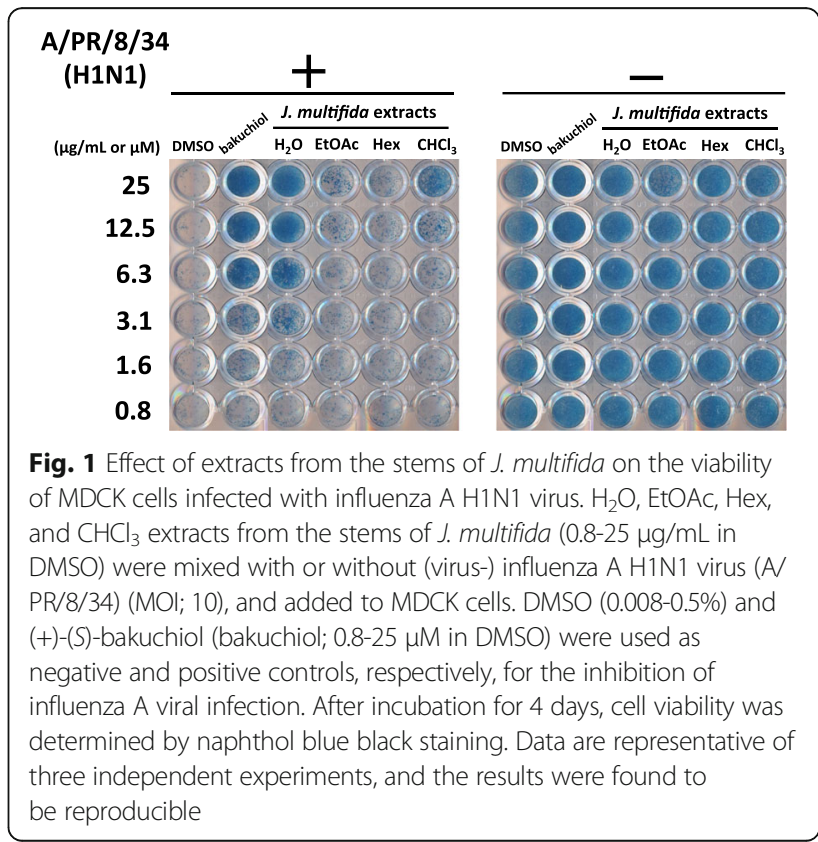




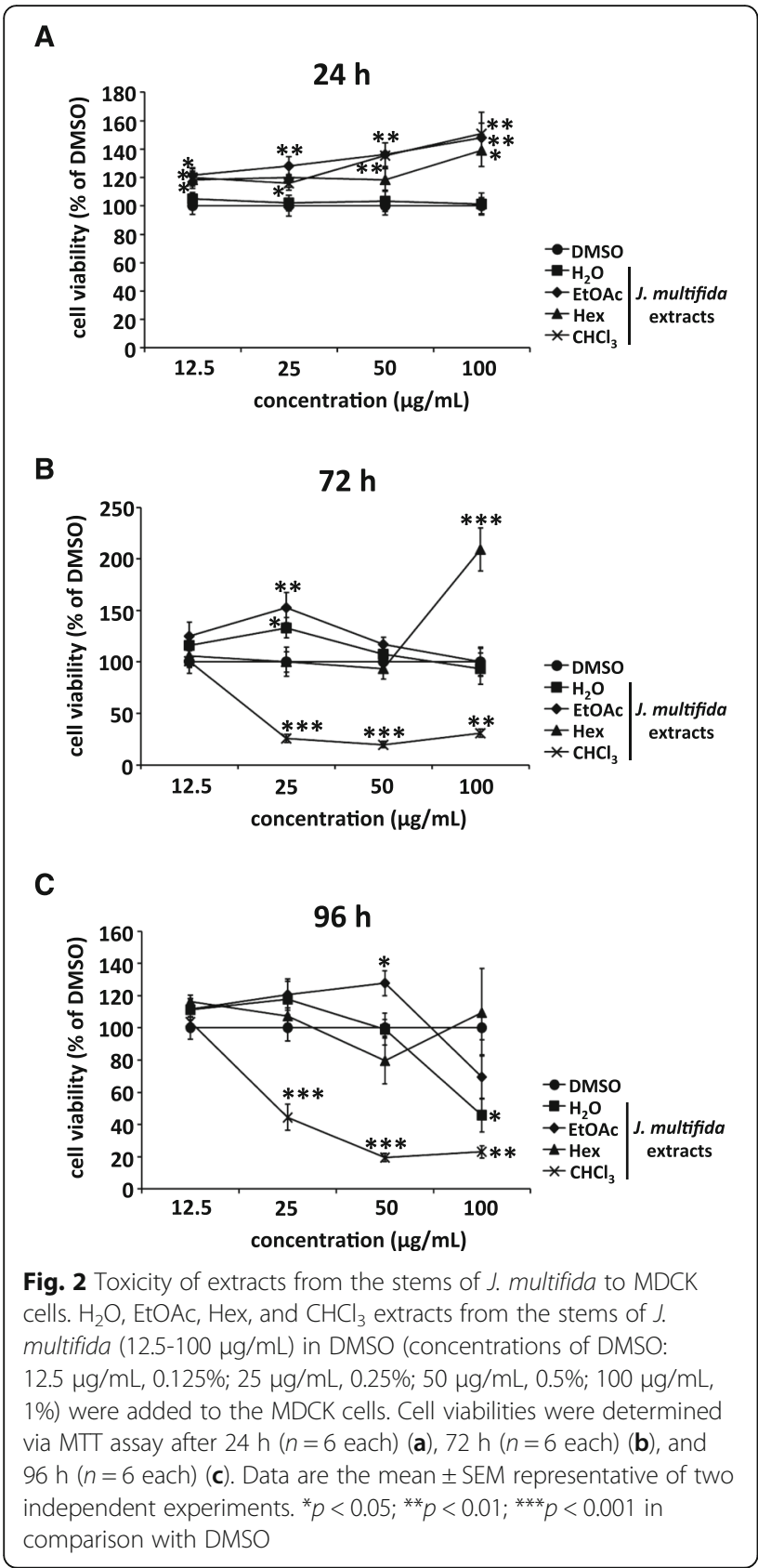

Hex, or $\leq 12.5 \mu \mathrm{g} / \mathrm{mL} \mathrm{CHCl}_{3}$ extracts was unaffected compared with cells exposed to DMSO only (Fig. 2c). Therefore, these data suggested that exposure to $\leq$ $100 \mu \mathrm{g} / \mathrm{mL} \mathrm{H}_{2} \mathrm{O}$, EtOAc, $\mathrm{Hex}$, or $\mathrm{CHCl}_{3}$ extract for $24 \mathrm{~h}$, or $\leq 50 \mu \mathrm{g} / \mathrm{mL} \mathrm{H}_{2} \mathrm{O}, \leq 100 \mu \mathrm{g} / \mathrm{mL}$ EtOAc and Hex, or $\leq 12.5 \mu \mathrm{g} / \mathrm{mL} \mathrm{CHCl}_{3}$ extracts for 72 or $96 \mathrm{~h}$ was not cytotoxic in MDCK cells.

Together, these results proved that the $\mathrm{H}_{2} \mathrm{O}$ extract from the stems of $J$. multifida promoted the survival of MDCK cells infected with the influenza A H1N1 virus. The EtOAc and $\mathrm{CHCl}_{3}$ extracts demonstrated similar, but weaker, effects.
The extracts inhibited influenza A viral infection and growth

To investigate whether the extracts inhibited viral infection, we examined viral NP-immunofluorescence staining in MDCK cells treated with a mixture of virus and $\mathrm{H}_{2} \mathrm{O}$, EtOAc, $\mathrm{Hex}$, or $\mathrm{CHCl}_{3}$ extract for 24 h. The wells were observed under a microscope and photographed (Fig. 3a). NP-immunostained cells were counted, and the percentage of influenza A NP-positive cells per DAPIpositive cells was calculated (Fig. $3 \mathrm{~b}$ ). The percentage of influenza A NP-positive cells was significantly decreased in a concentration-dependent manner in samples treated with $\mathrm{H}_{2} \mathrm{O}$, EtOAc, or $\mathrm{CHCl}_{3}$ extract or $(+)-(S)$-bakuchiol (positive control), compared with DMSO-treated cells (Fig. 3a and b). The $\mathrm{H}_{2} \mathrm{O}$ extract produced greater inhibition of influenza A viral infection than the other extracts. These data proved the inhibitory effect of the

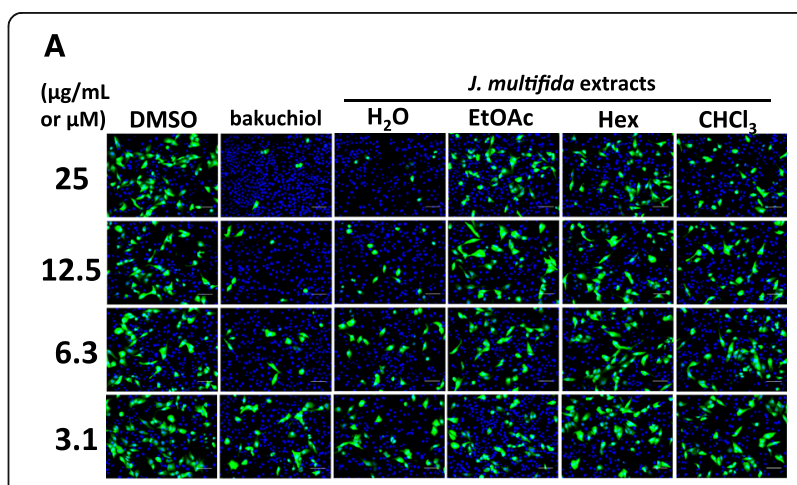

B

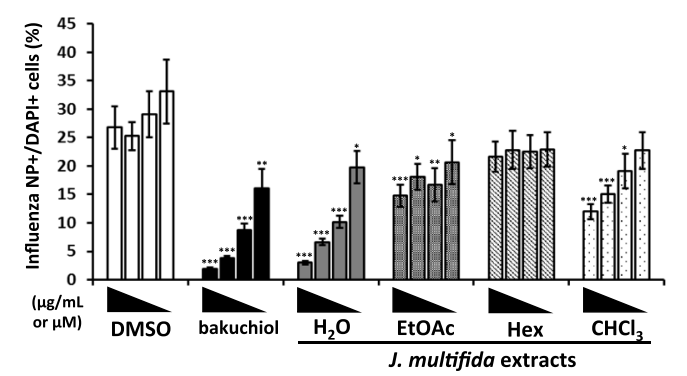

Fig. 3 Extracts from the stems of J. multifida inhibited influenza A $\mathrm{H} 1 \mathrm{~N} 1$ viral infection. $\mathrm{H}_{2} \mathrm{O}$, EtOAc, $\mathrm{Hex}$, or $\mathrm{CHCl}_{3}$ extracts from the stems of J. multifida (3.1-25 $\mu \mathrm{g} / \mathrm{mL})(n=9$ each) or (+)-(S)-bakuchiol (bakuchiol; 3.1-25 $\mu \mathrm{M})(n=9)$ were mixed with influenza A virus (A/PR/ $8 / 34)$ at a $\mathrm{MOl}$ of 0.1 and added to MDCK cells. DMSO (0.031-0.25\%) $(n=9)$ was used as the negative control. After $24 \mathrm{~h}$, the cells were fixed and permeabilized. To visualize influenza A virus-infected cells, we performed immunofluorescent staining of influenza A viral NP (green) and cell nuclei (b/ue), using the nuclear-staining compound, DAPI. Cells were subsequently photographed under a fluorescence microscope (a), and the percentage of influenza A viral NP-positive cells per DAPIpositive cells was calculated based on influenza A viral NP-positive and DAPI-positive cell numbers (b). The white scale bar in each image represents $100 \mu \mathrm{m}$. Data are presented as means \pm SEM of three independent experiments. ${ }^{*} p<0.05$; ${ }^{* *} p<0.01 ;{ }^{* * *} p<0.001$ in comparison with DMSO 
$\mathrm{H}_{2} \mathrm{O}$, EtOAc, and $\mathrm{CHCl}_{3}$ extracts from the stems of $J$. multifida on influenza A virus H1N1 infection.

Next, we investigated the inhibition of viral growth by the $\mathrm{H}_{2} \mathrm{O}$, EtOAc, Hex, or $\mathrm{CHCl}_{3}$ extract for 24-72 $\mathrm{h}$ in virus-infected MDCK cells. The viral titers in conditioned media from samples treated with $\mathrm{CHCl}_{3}$ extract between 48 and 72 h, EtOAc or Hex extracts at 72 h, and ribavirin between $24-72 \mathrm{~h}$ were significantly decreased compared with those in media conditioned by DMSO-treated cells (Fig. 4a). However, owing to the cytotoxicity observed following a 72-h exposure of MDCK cells to $25 \mathrm{\mu g} / \mathrm{mL} \mathrm{CHCl}_{3}$ extract in the viral growth experiment (Fig. 2b), we repeated the experiment

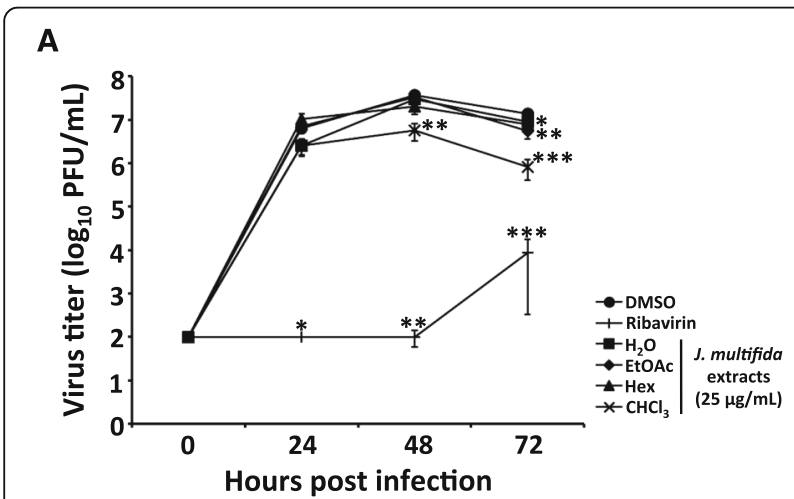

B

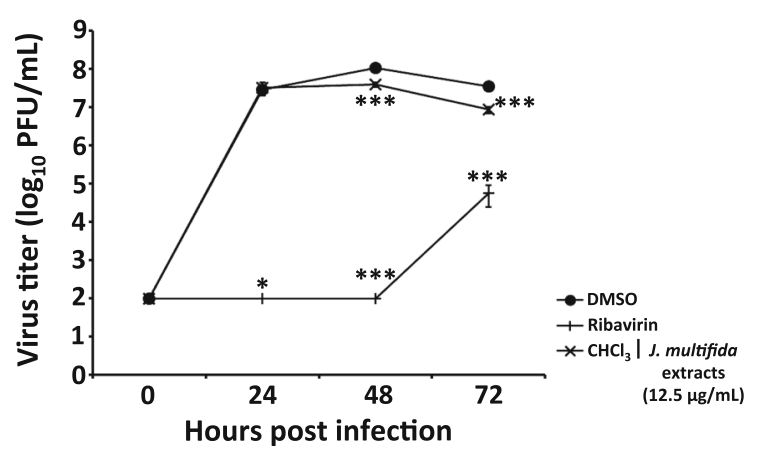

Fig. 4 Extracts from the stems of J. multifida inhibited influenza A $\mathrm{H} 1 \mathrm{~N} 1$ viral growth. MDCK cells were infected with A/PR/8/34 (MOl; 0.001 ) for $1 \mathrm{~h}$, and then the infected cells were washed. $\mathrm{H}_{2} \mathrm{O}$, EtOAc, $\mathrm{Hex}$, or $\mathrm{CHCl}_{3}$ extracts from the stems of J. multifida $(25 \mu \mathrm{g} / \mathrm{mL}$ in $0.5 \%$ DMSO) ( $n=7$ each) (a) were added to the cells in the infection medium supplemented with $3 \mu \mathrm{g} / \mathrm{mL}$ TPCK-treated trypsin. DMSO $(0.5 \%)(n=7)$ or ribavirin (50 $\mu \mathrm{M}$ in $0.5 \% \mathrm{DMSO})(n=7)$ were the negative and positive controls, respectively, for the inhibition of influenza A viral growth. In addition, the same experiment was performed with DMSO (0.5\%), ribavirin (50 $\mu \mathrm{M}$ in 0.5\% DMSO), and $12.5 \mu \mathrm{g} / \mathrm{mL} \mathrm{CHCl}_{3}$ extract from the stems of J. multifida (in $0.5 \%$ DMSO) ( $n=12$ each) (b). The conditioned culture medium was collected at the indicated time points, added to MDCK cells, and the treated cells were immunostained with an antibody to influenza A viral NP. The viral titers (PFU/mL) were calculated from the number of stained cells. The data are the mean \pm SEM representative of three independent experiments. ${ }^{*} p<0.05$; ${ }^{* *} p<$ $0.01 ;{ }^{* * *} p<0.001$ in comparison with DMSO with $12.5 \mu \mathrm{g} / \mathrm{mL} \mathrm{CHCl}_{3}$ extract. The viral titers in the conditioned media from cells treated with $12.5 \mu \mathrm{g} / \mathrm{mL}$ $\mathrm{CHCl}_{3}$ extract at 48 and $72 \mathrm{~h}$ significantly decreased compared with those in the media conditioned by DMSO-treated cells (Fig. 4b). These data proved that the EtOAc, $\mathrm{Hex}$, and $\mathrm{CHCl}_{3}$ extracts inhibited the growth of influenza $\mathrm{A} \mathrm{H} 1 \mathrm{~N} 1$ virus, and that the $\mathrm{CHCl}_{3}$ extract possessed the strongest activity.

Together, these results demonstrated the inhibition of influenza A viral infection and growth by extracts from the stems of $J$. multifida. The variation in the inhibitory effects of the extracts may be due to the polarities of the phytochemical constituents present in the stems.

\section{Discussion}

In the present study, the $\mathrm{H}_{2} \mathrm{O}$ extract from the stems of J. multifida strongly increased survival of influenza A virus-infected MDCK cells (Fig. 1) and inhibited influenza A viral infection (Fig. 3), whereas the $\mathrm{CHCl}_{3}$ extract demonstrated the strongest inhibition of influenza A viral growth (Fig. 4) compared with the other crude extracts. These results indicated that the different polarities of the $\mathrm{H}_{2} \mathrm{O}$ and $\mathrm{CHCl}_{3}$ crude extracts produced inhibition of viral infection or growth by different mechanisms. Infection with the influenza virus begins with binding to the surface of a host cell by viral hemagglutinin (HA), viral surface protein [19]. The influenza virus invades host cells by endocytosis, and the viral genome is then released into the host's cytoplasm through fusion of the viral membrane with the host endosomal membrane via HA cleavage. The influenza viral genome replicates in the host nucleus using viral RNA polymerase. The virions bud and are released from the membrane of the host cell using viral NA. In the cell viability and viral infection assays, the $\mathrm{H}_{2} \mathrm{O}$ extract from the stems of $J$. multifida inhibited influenza A viral binding to host cells when the influenza virus and extracts were co-incubated in advance. In contrast, in the viral growth assay, the $\mathrm{CHCl}_{3}$ extract inhibited influenza A viral replication in host cells. We therefore propose that the $\mathrm{H}_{2} \mathrm{O}$ extract may include compounds that inhibit influenza A viral binding to host cells surface, endocytosis, membrane fusion, or uncoating by inhibiting viral HA, while the $\mathrm{CHCl}_{3}$ extract may include compounds that inhibit influenza viral replication in host cells by inhibiting viral RNA polymerase or NA activities.

Previously, chemical studies of the stems of $J$. multifida led to the isolation of lathyrane-type diterpenoids [20-24], jatrophane-type diterpenoids [11, 22], and coumarino-type lignoids [22]. The lathyrane-type diterpenoids, multifidone, multifidanol, and multifidenol, showed cytotoxicity and antibacterial activity [24]. The jatrophane-type diterpenoid, jatrophone, was reported to possess a wide range of biological effects such as 
cytotoxicity and antitumor activity [25, 26]. However, the anti-influenza activity of the phytochemical constituents of $J$. multifida has not been yet investigated. The lathyrane-type diterpenoids from Euphorbia micractina showed the anti-HIV activity [27]. Dang et al. recently reported that the abietane-type tricyclic phenolic diterpenoids, (+)-podcarpic acid and (+)-totarol, inhibited influenza A H1N1 viral infection (A/PR/8/34) [28]. Therefore, the diterpenoids contained in $J$. multifida may confer the anti-viral effects such as anti-influenza and anti-HIV activities. It is expected that anti-influenza compounds will be isolated from the active crude extracts in our ongoing work.

\section{Conclusions}

The findings of the present study demonstrated that the most polar extract, the $\mathrm{H}_{2} \mathrm{O}$ extract, from the stems of $J$. multifida increased survival of MDCK cells infected with the influenza A H1N1 virus and showed the strongest inhibition of influenza A H1N1 viral infection in MDCK cells. Of the EtOAc, Hex, and $\mathrm{CHCl}_{3}$ extracts, the $\mathrm{CHCl}_{3}$ extract showed the strongest inhibition of influenza A H1N1 viral growth in MDCK cells. These results indicated that the stems of $J$. multifida could be used as a herbal medicine for the treatment of influenza and may be a source of candidate compounds for novel antiinfluenza drug development.

\section{Abbreviations \\ ANOVA: One-way analysis of variance; $\mathrm{CHCl}_{3}$ : Chloroform; DAPI: Diamidino-2- phenylindole; DMSO: Dimethyl sulfoxide; EtOAc: Ethyl acetate; $\mathrm{H}_{2} \mathrm{O}$ : Water; Hex: $n$-hexane; MDCK: Madin-Darby canine kidney; MTT: Thiazolyl blue tetrazolium bromide; NA: Neuraminidase; NP: Nucleoprotein; P/S: Penicillin and streptomycin; PBS: Phosphate-buffered saline; PR: Puerto Rico; TPCK: L- tosylamido-2-phenyl ethyl chloromethyl ketone}

\section{Acknowledgements}

Not applicable.

\section{Funding}

This research was performed as part of the Cooperative Research Project with the Institute of Natural Medicine, University of Toyama in 2016 (M.S., T.I., and T.K.). This work was also supported in part by a Grant-in-Aid for Scientific Research from the Ministry of Education, Culture, Sports, Science and Technology, Japan (H.M. and T.I.)

\section{Availability of data and materials}

The original data are available from the authors. The availability of all materials and reagents is detailed in this manuscript.

\section{Authors' contributions}

This study was designed by MS, TI, HM, and TK. MS performed all the experiments and drafted the manuscript. SYW and HM performed the plant extraction. AM performed the experiments with influenza virus. NNW and HN performed the plant harvesting and extraction. ET and HK performed the growth and purification of influenza virus. TI and TK critically reviewed the manuscript. All authors reviewed the manuscript, and read and approved the final version.

\section{Competing interests}

The authors declare that they have no conflicts of interest concerning this work.
Consent for publication

All authors agree to publish the manuscript in its present form.

\section{Ethic approval and consent participate}

Not applicable.

\section{Author details}

'Laboratory of Biochemistry, Faculty of Pharmaceutical Sciences, Tokushima Bunri University, 180 Yamashiro-cho, Tokushima 770-8514, Japan. ${ }^{2}$ Institute of Natural Medicine, University of Toyama, 2630, Sugitani, Toyama 930-0194, Japan. ${ }^{3}$ Department of Chemistry, University of Yangon, Yangon 11041, Myanmar. ${ }^{4}$ Division of Pathology and Metabolome Research for Infectious Disease and Host Defense, Institute for Enzyme Research, University of Tokushima, 3-18-15, Kuramoto-cho, Tokushima 770-8503, Japan.

Received: 29 September 2016 Accepted: 28 January 2017

Published online: 07 February 2017

\section{References}

1. Horimoto T, Kawaoka Y. Influenza: lessons from past pandemics, warnings from current incidents. Nat Rev Microbiol. 2005;3(8):591-600.

2. Itoh Y, Shinya K, Kiso M, Watanabe T, Sakoda Y, Hatta M, Muramoto Y, Tamura D, Sakai-Tagawa Y, Noda T, et al. In vitro and in vivo characterization of new swine-origin H1N1 influenza viruses. Nature. 2009;460(7258):1021-5.

3. Neumann G, Noda T, Kawaoka Y. Emergence and pandemic potential of swine-origin H1N1 influenza virus. Nature. 2009;459(7249):931-9.

4. Dortmans JC, Dekkers J, Wickramasinghe IN, Verheije MH, Rottier PJ, van Kuppeveld FJ, de Vries E, de Haan CA. Adaptation of novel H7N9 influenza A virus to human receptors. Sci Rep. 2013;3:3058.

5. Fiore AE, Fry A, Shay D, Gubareva L, Bresee JS, Uyeki TM. Centers for Disease C, Prevention: Antiviral agents for the treatment and chemoprophylaxis of influenza - recommendations of the Advisory Committee on Immunization Practices (ACIP). MMWR Recomm Rep. 2011;60(1):1-24.

6. Molinari G. Natural products in drug discovery: present status and perspectives. Adv Exp Med Biol. 2009;655:13-27.

7. Harvey AL, Edrada-Ebel R, Quinn RJ. The re-emergence of natural products for drug discovery in the genomics era. Nat Rev Drug Discov. 2015;14(2): $111-29$

8. Gao L, Sun Y, Si J, Liu J, Sun G, Sun X, Cao L. Cryptoporus volvatus extract inhibits influenza virus replication in vitro and in vivo. PLoS One. 2014;9(12): e113604.

9. Yang $\mathrm{CH}$, Tan $\mathrm{DH}$, Hsu WL, Jong $T$, Wen $\mathrm{CL}$, Hsu SL, Chang PC. Antiinfluenza virus activity of the ethanolic extract from Peperomia sui. J Ethnopharmacol. 2014;155(1):320-5.

10. Rajasekaran D, Palombo EA, Chia Yeo T. Lim Siok Ley D, Lee Tu C, Malherbe F, Grollo L: Identification of traditional medicinal plant extracts with novel anti-influenza activity. PLoS One. 2013;8(11):e79293.

11. Sabandar CW, Ahmat N, Jaafar FM, Sahidin I. Medicinal property, phytochemistry and pharmacology of several Jatropha species (Euphorbiaceae): a review. Phytochemistry. 2013;85:7-29.

12. Falodun $A$, Imieje $V$, Erharuyi $O$, Joy A, Langer $P$, Jacob M, Khan S, Abaldry M, Hamann M. Isolation of antileishmanial, antimalarial and antimicrobial metabolites from Jatropha multifida. Asian Pac J Trop Biomed. 2014;4(5): 374-8.

13. Win NN, Ito $T$, Aimaiti $S$, Imagawa $H$, Ngwe $H$, Abe I, Morita $H$. Kaempulchraols A-H, Diterpenoids from the Rhizomes of Kaempferia pulchra Collected in Myanmar. J Nat Prod. 2015;78(5):1113-8.

14. Ito T, Nisa K, Kodama T, Tanaka M, Okamoto Y. Ismail, Morita H: Two new cyclopentenones and a new furanone from Baeckea frutescens and their cytotoxicities. Fitoterapia. 2016;112:132-5.

15. Shoji M, Arakaki Y, Esumi T, Kohnomi S, Yamamoto C, Suzuki Y, Takahashi E, Konishi S, Kido H, Kuzuhara T. Bakuchiol Is a Phenolic Isoprenoid with Novel Enantiomer-selective Anti-influenza A Virus Activity Involving Nrf2 Activation. J Biol Chem. 2015;290(46):28001-17

16. Takahashi E, Kataoka K, Indalao IL, Konoha K, Fujii K, Chida J, Mizuno D, Fujihashi K, Kido H. Oral clarithromycin enhances airway immunoglobulin A ( $\lg A)$ immunity through induction of IgA class switching recombination and B-cell-activating factor of the tumor necrosis factor family molecule on mucosal dendritic cells in mice infected with influenza A virus. J Virol. 2012; 86(20):10924-34. 
17. Shoji M, Takahashi E, Hatakeyama D, Iwai Y, Morita Y, Shirayama R, Echigo N, Kido H, Nakamura S, Mashino T, et al. Anti-influenza activity of c60 fullerene derivatives. PLoS One. 2013;8(6):e66337.

18. Shigeta S, Mori S, Watanabe J, Soeda S, Takahashi K, Yamase T. Synergistic antiinfluenza virus A (H1N1) activities of PM-523 (polyoxometalate) and ribavirin in vitro and in vivo. Antimicrob Agents Chemother. 1997:41(7):1423-7.

19. von Itzstein $\mathrm{M}$. The war against influenza: discovery and development of sialidase inhibitors. Nat Rev Drug Discov. 2007;6(12):967-74.

20. Das B, Laxminarayana K, Krishnaiah M, Srinivas Y, Raju TV. Multidione, a novel diterpenoid from Jatropha multifida. Tetrahedron Lett. 2009;50(34):4885-7.

21. Das B, Ravikanth B, Reddy KR, Thirupathi P, Raju TV, Sridhar B. Diterpenoids from Jatropha multifida. Phytochemistry. 2008;69(14):2639-41.

22. Das B, Reddy KR, Ravikanth B, Raju TV, Sridhar B, Khan PU, Rao JV. Multifidone: a novel cytotoxic lathyrane-type diterpene having an unusual six-membered $\mathrm{A}$ ring from Jatropha multifida. Bioorg Med Chem Lett. 2009:19(1):77-9.

23. Das B, Satya Kumar A, Narayan Kumar J, Venugopal Raju T. A new macrocyclic diterpenoid from Jatropha multifida. Nat Prod Res. 2010;24(16):1510-3.

24. Kanth BS, Kumar AS, Shinde DB, Babu KH, Raju TV, Kumar CG, Sujitha P, Das B. New bioactive macrocyclic diterpenoids from Jatropha multifida. Bioorg Med Chem Lett. 2011;21(22):6808-10.

25. Goel G, Makkar HP, Francis G, Becker K. Phorbol esters: structure, biological activity, and toxicity in animals. Int J Toxicol. 2007;26(4):279-88.

26. Theoduloz C, Rodriguez JA, Pertino M, Schmeda-Hirschmann G Antiproliferative activity of the diterpenes jatrophone and jatropholone and their derivatives. Planta Med. 2009;75(14):1520-2.

27. Tian Y, Xu W, Zhu C, Lin S, Li Y, Xiong L, Wang S, Wang L, Yang Y, Guo Y, et al. Lathyrane diterpenoids from the roots of Euphorbia micractina and their biological activities. J Nat Prod. 2011;74(5):1221-9.

28. Dang Z, Jung K, Zhu L, Xie H, Lee KH, Chen CH, Huang L. Phenolic diterpenoid derivatives as anti-influenza a virus agents. ACS Med Chem Lett. 2015;6(3):355-8.

\section{Submit your next manuscript to BioMed Central and we will help you at every step:}

- We accept pre-submission inquiries

- Our selector tool helps you to find the most relevant journal

- We provide round the clock customer support

- Convenient online submission

- Thorough peer review

- Inclusion in PubMed and all major indexing services

- Maximum visibility for your research

Submit your manuscript at www.biomedcentral.com/submit

) Biomed Central 